\title{
Succession Planning in Black-Owned Family Businesses: A South African Perspective
}

\author{
Mqoteleni Gomba ${ }^{1} \&$ Tumo Kele ${ }^{2}$ \\ ${ }^{1}$ Gordon Institute of Business Science, University of Pretoria, South Africa \\ ${ }^{2}$ Centre for Business Analysis and Research, Gordon Institute of Business Science, University of Pretoria, South \\ Africa
}

ORCID iD: 0000-0002-4118-5262

Correspondence: Tumo Kele, Centre for Business Analysis and Research, Gordon Institute of Business Science, University of Pretoria, South Africa. E-mail: kelet@gibs.co.za; keletp@gmail.com

Received: July 4, 2016

doi:10.5430/ijba.v7n5p9
Accepted: July 19, 2016

Online Published: August 28, 2016

URL: http://dx.doi.org/10.5430/ijba.v7n5p9

\begin{abstract}
A significant number of businesses existing in South Africa originated as family-owned businesses and contribute substantially to employment creation, poverty eradication and wealth creation. However, globally the longevity of family businesses through generations remains a major cause for concern for all stakeholders. South African economy is characterised by a history of apartheid, where prior to 1994, the black majority only owned less than 5 percent of the businesses active in the economy. The economy is swiftly taking a turn and more black businesses are emerging. This study focused on understanding the factors that influence succession planning decisions in black-owned family businesses. The study followed an exploratory qualitative approach, using semi-structured interviews. Thirteen black family-owned business owners were interviewed. The key findings showed that possible successors in family-owned businesses regard the successor-related factors as the predominant drivers of management succession. The successor's commitment to and interest in the business has a strong influence on decisions and criteria design across all the stages of the management succession process.
\end{abstract}

Keywords: management, succession planning, black family, family-owned business, South Africa

\section{Background and Introduction}

Family-owned businesses are amongst the most significant contributors to wealth and employment creation in essentially every economy in the world (Venter, Boshoff \& Maas, 2005). In South Africa, it is estimated that approximately $80 \%$ of all businesses belong to families (Van der Merwe, Venter \& Ellis, 2009). In South Africa most of the family businesses are classified as small-to-medium enterprises (SMEs) by virtue of their size and annual income. SMEs play a vital role in the economic activity as a source of job creation and economic wealth (Venter \& Boshoff, 2007). Nevertheless, the lack of sustainability of these businesses from generation to generation is a major cause for concern for many stakeholders, including the family, owners and government (Van der Merwe, 2011). According to Williams, Zorn, Crook and Combs (2013), nearly $66 \%$ of family businesses fail during the transfer to the second generation, with only $15 \%$ surviving the third generation transfer. Van der Merwe et al. (2009) argues that one of the core explanations for the excessive failure rate of first and second generation family-owned businesses is linked to their incapability to effectively manage and execute the process of ownership and properly managing succession from one generation to the next.

Until 1994, South Africa's black majority, which constitutes over $70 \%$ of the total population owned less than 5 percent of the country's private economy (Nevin, 2006:29). With the advent of democracy, there has been a conscious effort by government and business to increase the level of participation of black South African citizens in the country's economy through a variety of initiatives and support structures (Musengi, 2006), one of them being entrepreneurship. By 2006, it was estimated that the number of family-owned businesses in South Africa had surpassed the one million mark, mainly driven by the increased economic participation of black people in the South African economy (Africa Investor, 2010).

It is against this background that this study aims to explore the successor-related factors that influence management 
succession decisions in fully black family-owned businesses within the South African economy from the perspective of the current leader or founders of such businesses.

\section{Literature Review}

\subsection{Definition of a Family-Owned Business}

Brockhaus (2004) argued that the definition of a 'family-owned business' takes different shapes and forms with some researchers arguing that a family-owned business is any business in which the family members are affected by the business decisions. Other family business scholars argue that for a business to be classified as a family business, it is required that at least two family members are active in the management and/or ownership of the business (Wilson, Wright \& Scholes, 2013).

For the purpose of this study the definition by Venter et al.(2005) will be adopted which states that "a family business is one that is owned by members of the same family to shape and/or pursue the formal or implicit vision of the business and where it is the intention of the family members to hand the business over to the next generation or where the business has already been handed over to a family member to manage and/or control."

\subsection{Importance and Uniqueness of Family-Owned Businesses}

Family-owned businesses constitute between $80 \%$ to $98 \%$ of all businesses in the global free markets and employ between $50 \%$ to $75 \%$ of the world's working population demographic (Poza \& Daugherty, 2013). As Van Buuren (2007) attests, approximately $80 \%$ of all businesses in South Africa have family ownership and about $60 \%$ of all the listed companies on the Johannesburg Stock Exchange (JSE) had some family involvement, at least during their start-up phase. Williams et al. (2013) concur that family businesses are unique and influential in the business sphere and many agree that what makes these enterprises unique is the interaction of the family with business (Yu, Lumpkin, Sorenson \& Brigham, 2012).

In addition, in many instances where family members are involved in a family business, the business does not only serve as the family's main source of income but also a significant source of long-term wealth being both financial and socio-emotional support (Williams et al., 2013). Thus, sustainability and longevity are of critical importance to these kinds of enterprises.

\subsection{Dynamics of Family-Owned Businesses in South Africa}

In South Africa, a sizeable proportion of family-owned businesses are classified as small-to-medium-sized enterprises (SMEs), with approximately 50\% providing employment to less than 20 people per business (Van Buuren, 2007). Like in many other developed and developing economies, SMEs in South Africa continue to make a substantial and increasing contribution to economic activity and employment (Farrington, 2009).

However, it was only in 2011 when the first dedicated South African unit to deal with family business governance and consulting was established. This unit is called the Family Business Association of Southern Africa (FABASA). FABASA's mandate comprises several elements which include providing assistance to family businesses on corporate governance and adoption of best practices, and guidance with ownership and management succession planning (Family Business Association of Southern Africa, 2013).

\subsection{Succession Planning in Family-Owned Businesses}

Ward (2011) and Lee (2006) comment that maintaining continuity of a family-owned business is perhaps one of the toughest management jobs on the globe, because, over and above the normal typical business challenges, family businesses also face challenges of handling the human emotions associated with family power struggles, sibling rivalry, upholding family values, family conflict, autocratic paternalistic cultures, nepotism, rigidity in innovation, succession and resistance to change.

Lee (2006) further postulates that because of these challenges, management succession is probably the biggest challenge encountered by the majority of family-owned businesses. Primarily, the succession decision regarding the management or Chief Executive Officer (CEO) position being is one of the most contentious issues (Eddleston, Kellermans, Floyd, Crittenden and Crittenden, 2013).

A comprehensive succession plan for a family business normally encompasses the handover of both ownership and management control from the incumbent generation to the next (Brun de Pontet, Wrosch \& Gagne, 2007). Fahed-Sreih and Djoundourian (2006) suggest that to succeed as a family-owned business, family member have to consciously embark on a process of ensuring that there is effective succession planning. This process must also provide transparency, thereby reducing the kind of ambiguity that may ignite conflict within the family and possibly lead to 
the failure of the business rather than creating a focus on growth (Eddleston et al., 2013).

In this study the management succession process proposed by Le Breton-Miller, Steier and Miller (2004), which includes important contextual variables, such as the business environment, cultural, social and family norms embedded within the family business, were adopted. Their model divides the succession process into four main steps:

(i) establishing ground rules for successor identification,

(ii) developing successors,

(iii) successor selection, and

(iv) handover or transition. (See Figure 1)

Building on this model, this study involves a closer look at the identification, development and selection steps in the succession process and the factors that influence management succession decisions across each step. There are many factors entrenched in the family business model that influence the management succession planning process. Many succession problems associated with family businesses arise owing to influences that operate at the individual (incumbent and successor), family and business level (De Massis et al., 2008). This study, however only explored the successor-related factors.

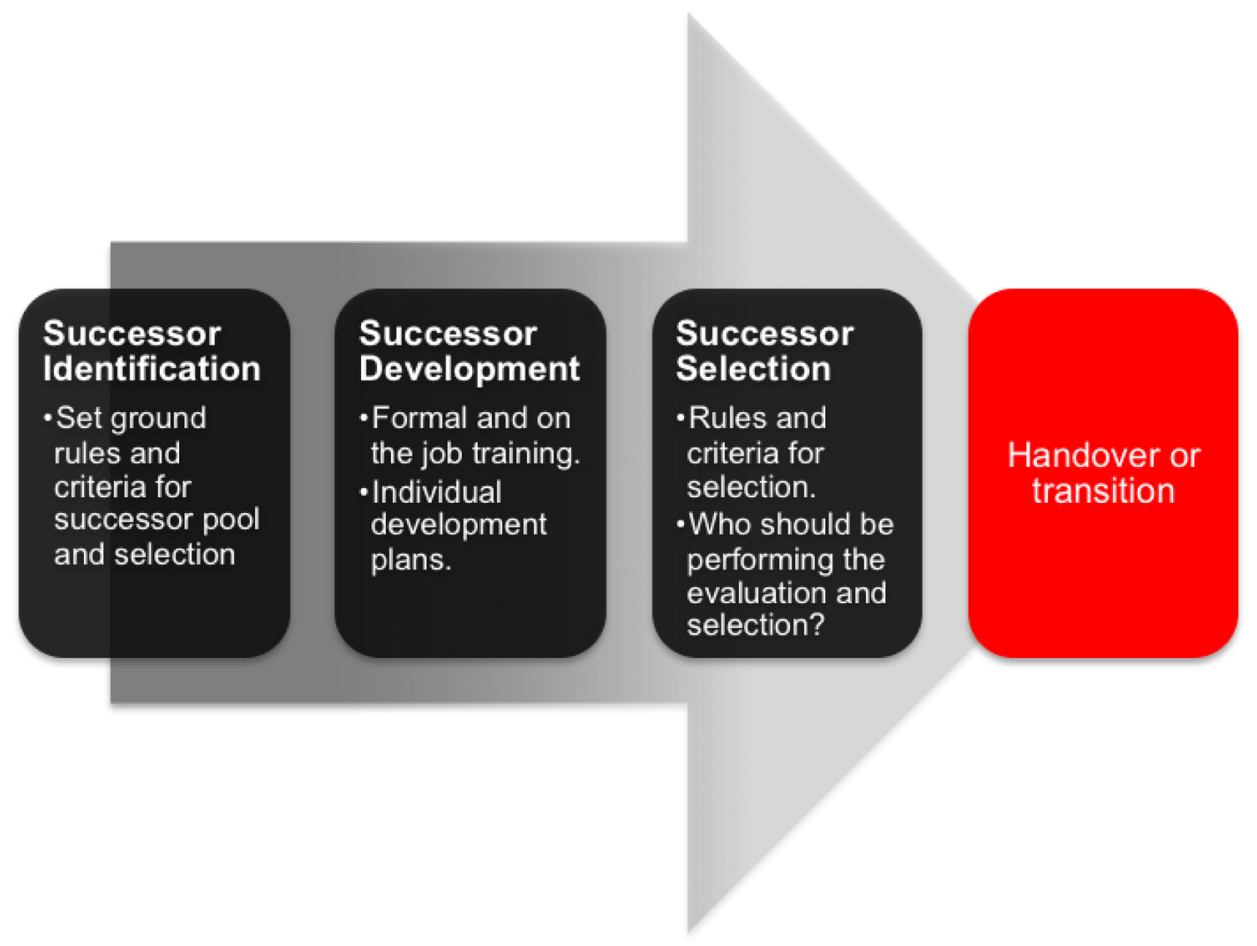

Figure 1. Management succession planning process

\section{Factors Influencing the Choice of Successor}

In any succession process, the successor is an important stakeholder who must effectively interact with other stakeholders in order to ensure support and understanding (Brun de Pontet et al., 2007); thus successor-related factors and their influence on the succession process must be understood for effective management succession.

Many authors on family business have suggested a number of desirable attributes in a successor that are considered important for effective succession planning. However the most comprehensive recent work on successor attributes was conducted by Chrisman, Chua and Sharma (1998). In this study, a total of 30 desirable successor attributes were identified. From the literature reviewed during this study, nine categories of successor-related factors, which influence management succession in a family-owned business, were identified as: 
- Quality of the relationship between the incumbent and successor

- The successor's commitment to and interest in the business

- Successor willingness to take over the business

- Successor capability in terms of competence and experience

- Successor personality traits and needs

- Quality of the relationship between the successor and the family members

- Support of the successor by the family members

- Natural succession and family standing

- Age of the successor

These factors are shown in Table1 with the supporting literature sources.

Table 1. Successor-related factors and literature sources

Successor-related factor
Quality of the relationship between
successor and incumbent

\section{Study or source}

Bracci and Vagnoni (2011), Cater III and Justis (2009), Venter et al. (2005), Le Breton-Miller et al. (2004), Sharma and Rao (2000), Chrisman et al. (1998).

Successor willingness to take over the business

Successor personality traits and needs

Successor capability in terms of competence and experience

The successor's commitment to and interest in the business

Age of the successor

Quality of the relationship between successor and the family members

Support of the successor by the family members

Natural succession and family Standing
Wiklund, Nordqvist, Hellerstedt and Bird (2013), Chrisman et al. (2009), Venter et al. (2005), Chrisman et al. (1998).

Van der Merwe (2011), Venter and Boshoff (2007), Venter et al. (2005), Le Breton-Miller et. al (2004), Chrisman et. al (1998).

Van der Merwe et. al (2009), Cater III and Justis (2009), (Brun de Pontet et al., 2007), Venter and Boshoff (2007), Devany (2006), Griffeth, Allen and Barret. (2006), Venter, Boshoff and Maas (2005), Sharma et al. (2000), Chrisman et al. (1998).

Van der Merwe (2011), Chrisman et al. (2009), Griffeth et al. (2006), Venter et al (2005), Sharma and Irving (2005).

Cabrera-Suarez and Martin-Santana (2012), Van der Merwe (2011), Vera and Dean (2005).

Chaimahawong and Sakulsriprasert (2013), Brun de Pontet et al. (2007), Griffeth et al. (2006), Chrisman et al. (1998).

Van der Merwe et al. (2012), De Massis et al. (2008), Brun de Pontet et al. (2007), Venter and Boshoff (2007),

Williams et al (2013), Steier and Miller (2010)

Chrisman et al. (2009). Griffeth et al. (2006) Sharma and Rao (2000). 


\section{Research Methodology}

In this study, we tried to uncover best practices for management successor identification, development and selection among South African black family-owned businesses, which is a relatively new area of research considering that 'blacks' only owned less than 5\% of the country's private economy before 1994. Owing to the fact that studies in this field have only recently been undertaken, an exploratory qualitative research design philosophy was adopted as the most appropriate for answering the research questions. The research process followed in this study took the form of a two-phased qualitative approach. In the first phase, a detailed review of current literature on family business and succession planning was conducted. The theory reviewed formed a basis to formulate the interview guide structure and questions used for the data collection process. The second phase involved individual face-to-face semi-structured qualitative interviews with 13 small to medium black family-owned business founders/owners or incumbents. The interviews lasted between 45 minutes and 60 minutes.

Sample: Although family-owned businesses have been in existence for as long as 300 years in the South African economy, it was only in 2011 when a unit or association was established to deal with the complex issues that family businesses face. A complete list of such enterprises in South Africa has not been determined to date. Therefore, for the purpose of this study, non-probability sampling was used. The sample members for this study were selected using a combination of purposive and snowball sampling methods. Participants in the study were selected on the basis of ease of access and number of years in business. Due to a lack of a known database for family-owned businesses in South Africa, a list (see Table 2) was developed through the snowballing method prior to and during to the interviews. The researcher conveniently selected the companies based on accessibility and industry type they operate in.

Table 2. Cases in the study

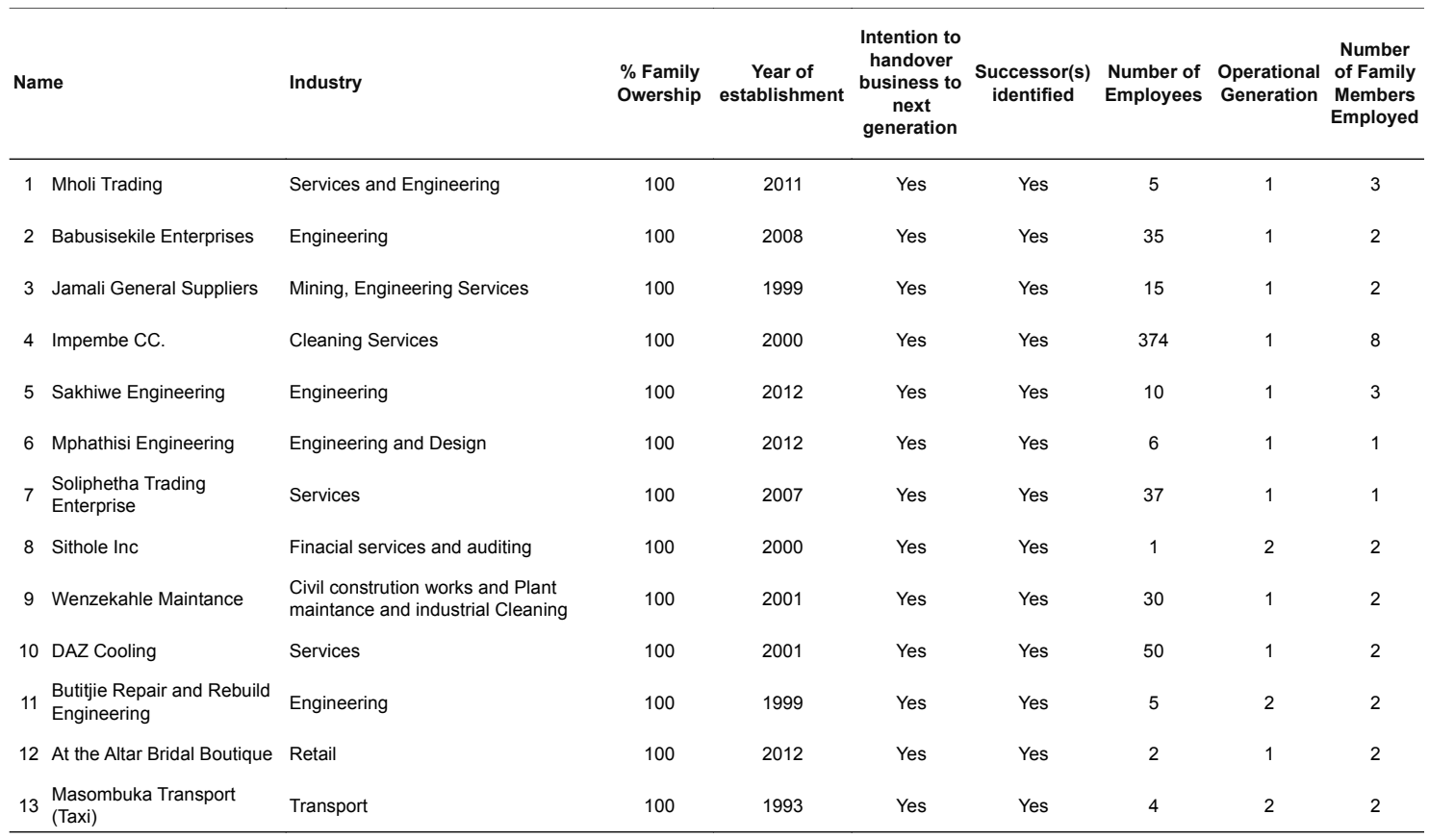

Data Analysis: Data collected was analysed using directed content and narrative analysis approaches to understand the functioning of each business and further to provide an indication about successor-related factors that influence management succession in black family-owned businesses that are most substantial and pervasive based on the opinions of the founders or current incumbents.

To specify the common themes in the research data, a numerical figure based on thenumber of respondents was used. The coding, management and analysis of the data was carried out using the computer-aided qualitative data analysis software (CAQDAS) called ATLAS.ti software system.

\section{Findings}

Several factors which influence management succession planning decisions in black family-owned businesses 
emerged from the interviews. Results from the interviews with the incumbents of the black family-owned businesses revealed that successor commitment, interest and willingness to take over the business are the most important factors that influence the overall management succession planning process. 'Successor commitment to and interest in the business', 'successor willingness to take over the business', 'quality of the relationship between the successor and incumbent', 'successor personality traits and needs' and 'successor capability in terms of competence and experience' were the more prominent factors for successor identification. When dealing with successor development, the interviewees felt that the quality of the relationship between the successor and incumbent, commitment and interest of successor in the business are also most important successor-related factors. Table 3 below summarises the results of the frequencies of the required factors based on emphasis ranking as they were mentioned during the semi-structured interviews with the founders or incumbents of the black family-owned businesses.

Table 3. Occurrence of the initial themes in the discussion per case

\begin{tabular}{|c|c|c|c|c|}
\hline & $\begin{array}{l}\text { Factors influencing management } \\
\text { successor identification, development and } \\
\text { selection in black family-owned } \\
\text { businesses }\end{array}$ & $\begin{array}{l}\text { Successor } \\
\text { Identification }\end{array}$ & $\begin{array}{c}\text { Successor } \\
\text { Development }\end{array}$ & $\begin{array}{l}\text { Successor } \\
\text { Selection }\end{array}$ \\
\hline 1 & $\begin{array}{l}\text { The successor's commitment to and interest } \\
\text { in the business }\end{array}$ & 12 & 9 & 9 \\
\hline 2 & $\begin{array}{l}\text { Quality of the relationship between the } \\
\text { successor and incumbent }\end{array}$ & 7 & 10 & 10 \\
\hline 3 & $\begin{array}{l}\text { Successor capability in terms of competence } \\
\text { and experience }\end{array}$ & 7 & 4 & 9 \\
\hline 4 & $\begin{array}{l}\text { Support of the successor by the family } \\
\text { members }\end{array}$ & 4 & 6 & 6 \\
\hline \multirow[t]{2}{*}{5} & Successor personality traits and needs & 7 & 1 & 5 \\
\hline & Natural succession & 7 & 0 & 2 \\
\hline 6 & $\begin{array}{l}\text { Successor willingness to take over the } \\
\text { business }\end{array}$ & 8 & 1 & 1 \\
\hline 7 & $\begin{array}{l}\text { Quality of the relationship between } \\
\text { successor and the family members }\end{array}$ & 4 & 0 & 3 \\
\hline 8 & Age of the successor & 2 & 1 & 0 \\
\hline 9 & $\begin{array}{l}\text { Timing of successor involvement in the } \\
\text { business }\end{array}$ & 0 & 2 & 2 \\
\hline 10 & Successor's risk appetite & 1 & 1 & 0 \\
\hline
\end{tabular}

The successor-related factors that were cited by the most respondents as possibly the most important in influencing decision-making during management succession planning are numbers 1-4 in Table 3 and will be discussed in more detail below, while the new themes that were identified for the first time by this study concerning the successor are numbers 9-10.

\subsection{Successor-related Factors Influencing Successor Identification}

\subsubsection{Commitment to and Interest in the Business}

The most cited factor by the respondents when identifying potential successors for the business was the successor's commitment to and interest in the business. Twelve of the 13 respondents mentioned the level of successor commitment and interest in the business as the main factor they will consider when identifying the talent pool of successors. They indicated that the successor's passion for business is a key ingredient, as seen in this quote:

That person must be committed in business, no matter what, because it's not always going to go as it is on paper. So they have to be committed in the business and they have to have passion for business in general 
and also for the industry we're in. So commitment and passion are the most important things that I would look at in the person who could be your potential successor.

5.1.2 Quality of the Relationship between the Successor and Incumbent

Throughout the discussions the relationship between the successor and the incumbent was mentioned several times. Seven out of 13 respondents believed that the relationship between the successor and incumbent is crucial to the successor identification process, when they said:

I think I want somebody that I have a good relationship with because someone that comes from outside, at the end of the day you come into the business and learn your day-to-day running's and he goes to register his own company.

\subsubsection{Successor Capability in Terms of Competence and Experience}

Seven of the 13 interviewees stated that the level of successor preparation in terms of competence and experience does impact the successor identification process. They mentioned that commitment and interest of the successor is not enough to guarantee he or she makes it into the talent pool. Rather, the successor must also demonstrate competency, experience and capabilities which are in line with the business function:

Firstly, their ability to develop the business - business development is key - and then good stakeholder investment and then creating networks which I think is very key in this role because you have to create the networks for you to succeed, and obviously the normal academic or financials and competencies and all those kind of things.

\subsubsection{Support of Successor by Family Members}

As detailed by the system theory of family business, family system will always influence the business system and the same applies to management succession of such businesses. Four of the 13 respondents said that they perceived support for the identified successors by family members, whether involved directly or indirectly in the business, has a significant influence on who is selected to be in the talent pool:

These are the people that my wife is comfortable with, she has known for them for some time.

\subsection{Successor-related Factors Influencing Successor Development}

\subsubsection{The Successor's Commitment to and Interest in the Business}

Nine out of the 13 respondents said that the successor levels of commitment and interest in the business are important in ensuring that the successor receives the appropriate training and development. They mentioned that most of the training will mostly be internal or on the job, for example:

You can train them but if a person doesn't have a passion for this. You know now, if they come to your office, we beg, we beg, we beg. Yeah you can see if this person knows what he is talking about and if he doesn't know, he is willing to learn.

If the successor is committed to and interested in the business, then the mentorship process between the incumbent and the potential successors can progress smoothly.

\subsubsection{Quality of the Relationship between the Successor and Incumbent}

Proper nurturing forms a critical part in the preparation of a capable and competent successor who will be ready to take over the business when the time comes. The interaction between the incumbent and the successor is critical at this stage and thus ten of the 13 respondents suggested that their relationship would be a building block to successful and meaningful development in terms of mentoring and communication:

I am going to expose somebody to the so-called family secret if I can call it that and then they can take the concept and then completely move it around and then that completely takes away the entire inheritance or the succession because now this is a different bloodline that we are looking at compared to the original blood line that we are trying to carry but again it's a trust element but complete transparency and letting go.

\subsubsection{Support of Successor by Family Members}

For any successors to develop optimally, they need to know that they can make mistakes and learn from them without consequences that will limit their creativity and ability to explore new avenues for the business. However, in a family business setting, not only must the incumbent support the successor during development, the family also has a role to play. Six of the 13 respondents agreed with this observation: 
From the family's side, their support for the successor will help a lot by not passing judgment if there are mistakes that have been made.

\subsection{Successor-related Factors Influencing Successor Selection}

\subsubsection{The Successor's Commitment to and Interest in the Business}

Successor commitment and passion for the business was seen by nine of the 13 respondents as the most important successor-related factors that they will consider when selecting their successor; this is illustrated by the quote below:

I want somebody, for me the most important thing, I want somebody who is going to be committed in the business. Somebody who is going to make sure that how they found the business, they're going to keep it like that.

\subsubsection{Quality of the Relationship between Successor and Incumbent}

When appointing the new incumbent, 10 of the 13 respondents mentioned that the closeness and loyalty of the successor towards them will have an over-arching influence on whom they select:

Everybody sees that Florence is closer to me and when I go to meetings and do everything, I do it with

Florence. So that alone, it will show the people that Florence is the person in charge when I am not there. I

am already starting now.

\subsubsection{Successor's Capability in Terms of Competence and Experience}

Nine of the 13 respondents mentioned successor preparedness in the form of competence and experience as one of the most important determinants of a successful succession. They said that the successor must be capable of managing the business, with business development skills being labelled as paramount:

Umm, first thing I need to identify whether he will be capable.

What I consider is this guy capable, is he well equipped, that's what is good for the business.

On-the-job training or internal preparation and the successors having demonstrated that they can manage the business operations on their own were considered as significant events that will influence the selection of the successor. The following quotations demonstrate the importance of on-the-job preparation:

Because whenever one goes on holiday, you take one person and he acts for you. She acts for you for some time you know. And based on those issues you use those systems of seeing by the time I was out of work who was able to ensure that things operate as normal.

\subsubsection{Support of Successor by Family Members}

The interaction of the family with business is a key distinguishing factors for a family business. Six of the 13 interviewees agreed that during successor selection, it is important that the family demonstrate support for the selected new incumbent.

I have trained XXX now to say look you have to support the successor of the business in whichever way as you agree on in the shares, that is what counts, the rest will fall into place as we go along.

\subsection{New Themes Regarding Successors}

From the data collected, a few responses of the interviewees could not be grouped into the initial themes. In terms of successor-related factors, these are the 'timing of successor's involvement in the business' and the 'successor's risk appetite'. The timing of the successor's involvement in the business was found to positively influence development and final selection. Successor's risk appetite on the other hand was established to influence both the successor identification and development process.

\subsubsection{Timing of Successor Involvement in the Business}

Two of the 13 respondents revealed that the timing of when the potential successor joins the business would inform their grooming process:

...it was not that difficult because they started grooming me when I was about 8 or 9 , and I started working with my uncle from 8/9 in his business.

We don't want to involve them in the business too early then they get big heads and they think they have a business. 


\subsubsection{Successor's Risk Appetite}

One of 13 respondents mentioned that the successor's risk appetite would influence successor identification for their business:

They would have to understand that while my mother is risk adverse, her three sons are very risk aggressive.

Regarding successor development, one of the 13 interviewees also raised the point that the successor must not have a high-risk appetite during his or her development because as a founder of the business he has taken many risks to get the business where it is now. The successor must be developed to make informed decisions and take calculated risks:

I have been a risk-taker for some time, for this business to be where it is, I don't want them to be risk takers,

I want them to take informed decisions, I want them to be in a position to say look, this is the decision I am taking and its informed, I don't want them to just go in and do whatever.

\section{Discussion of Findings}

The results were tested against the literature background and the problem statement.

\subsection{Successor-related Factors Influencing Successor Identification}

\subsubsection{The Successor's Commitment to and Interest in the Business}

Venter et al. (2005) concludes that the motivation of successors to enter the family business must be based on right reasons and it is vital that parents or incumbents do not pressurise their children into joining the business as employees. Venter et al. (2005) argues that this option should only be provided when and if the offspring or potential successors are interested and possess the necessary qualifications. This concurs broadly with the data showing that the incumbents strongly considered the potential successors' passion and commitment towards the business when identifying them for the talent pool of the business. It is important that the successor wants the job for the correct reasons, for example, trusting they can add value to the business as compared to feeling an obligation to take the job or lacking other viable career choices (Sharma \& Irving, 2005).

\subsubsection{Quality of the Relationship between Successor and Incumbent}

Le Breton-Miller et al. (2004) concludes that the incumbent is the most important factor in the success of family-owned business succession and his or her relationship with the successor plays a vital role throughout the succession planning process. The literature on family business succession contends that a positive relationship between the incumbent and the successor is fundamental to successful succession even prior to the successor joining the family business (Cater III \& Justis, 2009). The findings supported these views, showing that the quality of the relationship between the incumbent and the successor would play a role during successor identification.

\subsubsection{Successor Capability in Terms of Competence and Experience}

The data revealed that the incumbents identified the initial capabilities of the successors as important when selecting them for the family business succession talent pool. Business development skills and experience in the specific industry were identified as key initial competencies for the successors. This finding concurs with literature. Sharma et al. (2000) argues that the incumbent's confidence in the abilities of a potential successor would influence the extent to which a family engages in succession planning and therefore will tend to influence the initial stages of the succession process.

\subsubsection{Support of the Successor by the Family Members}

Van der Merwe et al. (2012) states that commitment of the family to business continuity is essential for the family as it supports the development of the shared future vision and the family business continuity plan. To show evidence of that commitment, the data revealed that the support of the potential successors by the family members is critical for long-term business continuity. According to the incumbents, the family must be comfortable with the succession talent pool and that the successor must have a good relationship with the family members.

\subsection{Successor-related Factors Influencing Successor Development}

\subsubsection{The Successor's Commitment to and Interest in the Business}

According to De Massis et al. (2008), failure by the incumbent to ensure that the potential successor possesses the essential skills to take over the management of the business may result in succession not taking place because such underdevelopment may either lead the successor to decline the position or cause the family and business to reject the successor. However, the data revealed that the incumbents view commitment, interest and eagerness of the successor to learn as a catalyst to the successor development process. Giarmarco (2012) suggests that to develop the right successor 
to enable the existing incumbent to walk away from the day-to-day operations requires long-term planning and is a process that happens over many years.

\subsubsection{Quality of the Relationship between Successor and Incumbent}

The findings revealed that the incumbents believed mentorship and on-the-job training played a critical part during successor development, with them being the main custodians. Sharma and Rao (2000) contend that one of the important aspects in the succession process is knowledge transfer, which may help develop and maintain competitive advantage for the family business. Sharma and Rao (2000) further argue that the most valuable resources and competences for family-owned businesses are those that are based on information and tacit knowledge and are commonly associated with the business incumbent. Ten of the 13 incumbents interviewed stressed that they found it difficult to groom a successor who did not trust their competencies. Hansen (1999), as cited in Bracci and Vagnoni (2011), suggests that the effectiveness of knowledge exchange hangs on the strength of the relationship between the incumbent and the successor and that such a relationship should be based on intimacy and trust.

\subsubsection{Timing of Successor Involvement in the Business}

Sharma and Rao (2000) conclude that early exposure to the family business through lower category jobs serves as valuable experience for successors. Such an environment allows the successor to acquaint himself or herself with the nature of the business and its employees and thus developing the necessary capabilities required for the business. The data concurred with this notion, presenting that the difficulty level of the successor grooming process was directly related to the age at which the successors joined the business. The earlier they joined, the easier it was for the incumbents to groom them.

\subsubsection{Support of the Successor by the Family Members}

Tatoglu, Kula, and Glaister (2008) report that family members who are not active in the family business have significant influence during the management succession process, especially the mother of the successor who acts as a 'silent mediator' between the generations. The findings reveal that the mother fulfilled an important role in ensuring the successors stayed focused during their development and pushed them to report for work like any other employee of the business. Sharma and Rao (2000) recount that the incumbent's ability to create and advance a business environment in which the successor feels free to make decisions and mistakes is essential to the successor's overall development. From the data collected it is clear that the incumbents fully grasped this idea and supported it, because if the family does not agree with the identified potential successor, the grooming process will not go smoothly and might even lead to the successor not being treated fairly when she or he has made bad business decisions.

\subsection{Successor-related Factors Influencing Successor Selection}

\subsubsection{The Successor's Commitment to and Interest in the Business}

Chrisman et al. (2009) argues that if the potential successor lacks commitment and trustworthiness, he or she will not have the support needed to implement a long-term strategy. The data strongly concur with this idea, revealing that the incumbents valued the successor's commitment to and interest in the business as critical success factors in leading the family business beyond their involvement. Van der Merwe (2011) also supports this data by saying that the lack of interest on the part of the successor to take over the family business may result in failure mainly because a reluctant successor will not be fully committed and therefore may not cooperate in the transition process.

\subsubsection{Quality of the Relationship between Successor and Incumbent}

If there is conflict between the incumbent and the successor, the succession process might be negatively impacted because the potential successor may decide to leave the business or the incumbent might not endorse his or her appointment (De Massis et al., 2008). The findings reveal that the closeness of the relationship between the two parties has a positive influence on successor selection. Venter et al. (2005) states that chances of a successful succession improve when the relationship between the incumbent and the successor is grounded on mutual understanding concerning the future of business.

\subsubsection{Successor's Capability in Terms of Competence and Experience}

In almost all businesses, the successor generally acquires control or authority out of experience and proven competence (Brun de Pontet et al., 2007). Such experience in the family business allows the successor to develop relationships within the business and understand its culture and complexities (Chrisman et al., 1998). The data of this study concurs with this notion, thus showing that the capability of the successor to manage, lead and develop the business will form a vital part of the final successor selection criteria for the family business. The successor's skills, experience and capabilities in leading businesses are essential requirements to gain credibility and legitimacy (Bracci \& Vagnoni, 
2011). "The succession process is only complete when the successor has gained legitimacy and is widely accepted by the stakeholders" (Tatoglu, Kula \& Glaister, 2008, p.161).

\subsubsection{Support of the Successor by the Family Members}

Lansberg (1999) as cited in Brun de Pontet et al. (2007) postulates that the current incumbent's immediate family or key employees might have personal vested interest in the succession process and could potentially contribute to the incumbent's reluctance to hand over the business because they fear what this change could mean for them. De Massis et al. (2008) argues that some family members holding influential positions might threaten to leave the business as a result of feeling discontent with the chosen successor. Under such circumstances, in order to bring them back into the business, the dominant powers-that-be within the family may decide not to go ahead with the appointment of a particular successor. The data moderately agreed with literature, showing that it was to some degree important for the successor to have full family backing when taking over the company's highest decision-making role.

\section{A Conceptual Model}

The findings revealed that the factors that influence decisions at each stage of the management succession process within a family business vary in terms of amount of influence and concentration. The following framework was developed to depict the influence of successor-related factors on management successor identification, development and selection in black family-owned businesses. These factors are presented as they appeared in the literature and were tested against the data collected.

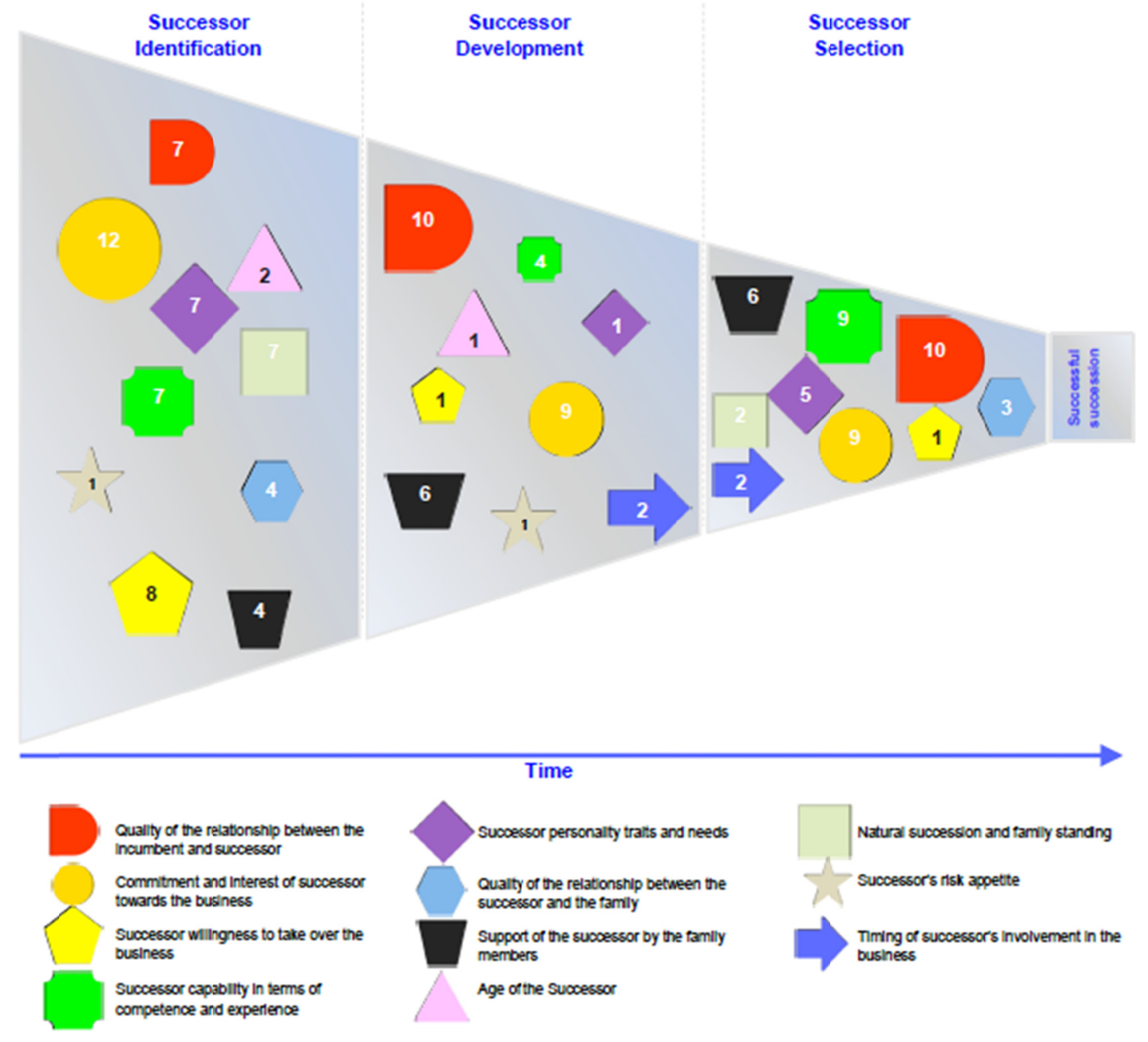




\section{Conclusions}

The findings revealed that the black family-owned business incumbents see successor-related factors and incumbent-related factors as the predominant factors that will influence management successor identification, development and selection in the business. The successor's commitment to and interest in the business and the quality of the relationship between the incumbent and the successor are very important for the overall management succession process. The incumbents stated that passion, commitment and interest in the business will sometimes even outweigh capability and other important factors to consider because a committed successor will withstand the testing times of running an SME in the South African economy. Driven by trust issues, the incumbents stated a strong preference for a successor with whom they have a good relationship. As a result, they should most carefully consider the family member best suited to taking over the business.

\section{References}

Africa Investor. (2010, November 1). Keeping it in the family. Retrieved December 19, 2013, from http://www.africainvestor.com/article.asp?id=7949

Bracci, E., \& Vagnoni, E. (2011). Understanding small family business succession in a knowledge management perspective. Journal of Knowledge Management, 9(1), 7-37.

Brockhaus, R. H. (2004). Family business succession: Suggestions for future research. Family Business Review, 17(2), 165-177. http://dx.doi.org/10.1111/j.1741-6248.2004.00011.x

Brun de Pontet, S., Wrosch, C., \& Gagne, M. (2007). An exploration of the generational differences in levels of control held among family businesses approaching succession. Family Business Review, 20(4), 337-354. http://dx.doi.org/10.1111/j.1741-6248.2007.00103.x

Cabrera-Suarez, M. K., \& Martin-Santana, J. D. (2012). Successor's commitment and succession success: dimensions and antecedents in the small Spanish family firm. International Journal of Human Resource Management, 23(13), 2736-2762. http://dx.doi.org/10.1080/09585192.2012.676458

Cater III, J. J., \& Justis, R. T. (2009). The development of successors from followers to leaders in small family firms: An exploratory study. Family Business Review, 22(2), 109-124. http://dx.doi.org/10.1177/0894486508327822

Chrisman, J. J., Chua, J. H., \& Sharma, P. (1998). Important Attributes of Successors in Family Businesses: An Exploratory Study. Family Business Review, 11(1), 19-34. http://dx.doi.org/10.1111/j.1741-6248.1998.00019.x

Chrisman, J. J., Chua, J. H., Sharma, P., \& Yoder, T. R. (2009). Guiding Family Businesses Through the Succession Process. CPA Journal, 79(6), 48-51.

Chua, J. H., Chrisman, J. J., \& Sharma, P. (2003). Succession and nonsuccession concerns of family firms and agency relationship with nonfamily managers. Family Business Review, 16(2), 89-107.

De Massis, A., Chua, J. H., \& Chrisman, J. J. (2008). Factors Preventing Intra-Family Succession. Family Business Review, 21(2), 183-199. http://dx.doi.org/10.1111/j.1741-6248.2008.00118.x

Devany, C. (2006). All in the family: Succession planning in a family business is important for keeping family and business intact. Journal of Property Management, 71(5), 14-14.

Eddleston, K. A., Kellermanns, F. W., Floyd, S. W., Crittenden, V. L., \& Crittenden, W. F. (2013). Planning for Growth: Life Stage Differences in Family Firms. Entrepreneurship Theory and Practice, 37(5), 1177-1202. http://dx.doi.org/10.1111/etap.12002

Fahed-Sreih, J., \& Djoundourian, S. (2006). Determinants of Longevity and Success in Lebanese Family Businesses: An Exploratory Study. Family Business Review, 19(3), 225-234.

Family Business Association of Southern Africa. (2013). Fabasa [About FABASA]. Retrieved December 19, 2013, from http://www.fabasa.co.za/about/fabasa-objectives/

Farrington, S. (2009). Sibling partnerships in South African small and medium-sized family businesses (Unpublished doctoral dissertation). Nelson Mandela Metropolitan University, Port Elizabeth, South Africa.

Giarmarco, J. (2012). The Three Levels of Family Business Succession Planning. Journal of Financial Service Professionals, 66(2), 59-69.

Griffeth, R. W., Allen, D. G., \& Barrett, R. (2006). Integration of family-owned business succession with turnover and life cycle models: Development of a successor retention process model. Human Resource Management Review, 16(2), 490-507. http://dx.doi.org/10.1016/j.hrmr.2006.08.006 
Le Breton-Miller, I., Steier, L. P., \& Miller, D. (2004). Toward an Integrative Model of Effective FOB Succession. Entrepreneurship Theory and Practice, 28(4), 305-328. http://dx.doi.org/10.1111/j.1540-6520.2004.00047.x

Lee, J. (2006). Family Firm Performance: Further Evidence. Family Business Review, 19(2), 103-114.

Musengi, S. (2006). Passing the spear: A grounded theory study of the influence of family business value sets on succession planning in black family-owned businesses (Unpublished doctoral dissertation). Rhodes University, Grahamstown.

Nevin, T. (2006). South Africa's black companies forge ahead. (cover story). African Business, (319), 29-29.

Poza, E., \& Daugherty, M. S. (2013). Family business (4th ed.). Cengage Learning.

Sharma, P., Chua, J. H., \& Chrisman, J. J. (2000). Perceptions About the Extent of Succession Planning in Canadian Family Firms. Canadian Journal of Administrative Science, 17(3), 233-244. http://dx.doi.org/10.1111/j.1936-4490.2000.tb00223.x

Sharma, P., \& Irving, P. G. (2005). Four Bases of Family Business Successor Commitment: Antecedents and Consequences. Entrepreneurship Theory and Practice, 29(1), 13-33.

Sharma, P., \& Rao, A. S. (2000). Successor Attributes in Indian and Canadian Family Firms: A Comparative Study. Family Business Review, 13(4), 313-330. http://dx.doi.org/10.1111/j.1741-6248.2000.00313.x

Steier, L. P. \& Miller, D. (2010). Pre- and post-succession governance philosophies in entrepreneurial family firms. Journal of Family Business Strategy, 1(3), 145-154. http://dx.doi.org/10.1016/j.jfbs.2010.07.001

Tatoglu, E., Kula, V., \& Glaister, K. W. (2008). Succession Planning in Family-owned Businesses: Evidence from Turkey. International Small Business Journal, 26(2), 155-180. http://dx.doi.org/10.1177/0266242607086572

Van Buuren, R. B. (2007). The life and times of a family business: A case study (PhD Thesis). University of the Free State, Bloemfontein.

Van der Merwe, S. (2011). An investigation into the suitability of younger generation successors in small and medium-sized family businesses. South African Journal Of Business Management, 42(1), 31-44.

Van der Merwe, S., Venter, E. \& Farrington, S. (2012). An assessment of selected family business values in small and medium-sized family businesses. South African Journal of Business Management, 43(4), 17-31.

Van der Merwe, S. P. \& Ellis, S. M. (2007). An exploratory study of some of the determinants of harmonious family relationships in small and medium-sized family businesses. Management Dynamics, 16(4), 24-35.

Van der Merwe, S. P., Venter, E., \& Ellis, S. M. (2009). An exploratory study of some of the determinants of management succession planning in family businesses. Management Dynamics, 18(4), 2-17.

Venter, E. \& Boshoff, C. (2007). The influence of organisational-related factors on the succession process in a small and medium-sized businesses. Management Dynamics. 16(1), 42-55.

Venter, E., Boshoff, C., \& Maas, G. (2005). The Influence of Successor-Related Factors on the Succession Process in Small and Medium-Sized Family Businesses. Family Business Review, 18(4), 283-303.

Vera, C. F. \& Dean, M. A. (2005). An Examination of the Challenges Daughters Face in Family Business Succession. Family Business Review, 18(4), 321-343. http://dx.doi.org/10.1111/j.1741-6248.2005.00051.x

Ward, J. L. (2011). Keeping the family business healthy: How to plan for continuing growth, profitability, and family leadership. Macmillan. http://dx.doi.org/10.1057/9780230116122

Wiklund, J., Nordqvist, M., Hellerstedt, K., \& Bird, M. (2013). Internal Versus External Ownership Transition in Family Firms: An Embeddedness Perspective. Entrepreneurship Theory and Practice, 37(6), 1319-1340. http://dx.doi.org/10.1111/etap.12068

Williams, D. W., Zorn, M. L., Crook, T. R. \& Combs, J. G. (2013). Passing the Torch: Factors Influencing Transgenerational Intent in Family Firms. Family Relations, 62(3), 415-428. http://dx.doi.org/10.1111/fare.12016

Wilson, N., Wright, M., \& Scholes, L. (2013). Family Business Survival and the Role of Boards. Entrepreneurship Theory and Practice, 37(6), 1369-1389. http://dx.doi.org/10.1111/etap.12071

Yu, A., Lumpkin, G. T., Sorenson, R. L. \& Brigham, K. H. (2012). The Landscape of Family Business Outcomes: A Summary and Numerical Taxonomy of Dependent Variables. Family Business Review, 25(1), 33-57. http://dx.doi.org/10.1177/0894486511430329 